\title{
A regional agricultural model for reallocation of water resources in central-eastern Tunisia
}

\author{
Houcine Jeder*, Zina Dbouba**, Ayoub Fouzal ${ }^{\star \star}$
}

DOI: $10.30682 / \mathrm{nm} 2003 \mathrm{e}$

JEL codes: Q1, Q24, Q25

\begin{abstract}
Good management of water resources requires a good allocation of their availability, especially in public irrigated schemes in Tunisia. This paper contributes to a better reallocation of available water resources at the farm and regional levels. A case study was discussed in the Kalâa Kebira region, in the centereast of Tunisia. Regional models based on aggregation and the possibility of water transfer between two irrigated schemes was tested. The results show that a good seasonal allocation is possible with a total regional exchange of $9.60 \% \mathrm{~m}^{3}$ of water available between these two schemes. This reallocation is beneficial at the regional level, recording an increase of $2.12 \%$ in agricultural income and less beneficial, except for farms that are less competitive, in terms of use of water resources. This reallocation also allows for cultural diversity and specification of agricultural farms. Competitiveness in the water use, diversification and specification of agricultural production systems help to preserve natural resources but they also help to satisfy demand of the regional market.
\end{abstract}

Keywords: Water resources, Agriculture, Reallocation, Aggregated, Regional model, Kalâa Kebira, Central East Tunisia.

\section{Introduction}

In Tunisia, water sector, characterized by spatial and temporal scarcity and irregularity, is currently facing major challenges such as an increasing demand. Agriculture still remains the most important sector of macro-economy. The sector accounts for only around $8.7 \%$ of Gross Domestic Product (GDP) but employs around $16.2 \%$ of the total employment in the country (World Bank, 2016). However, this sector consumes $75 \%$ of the mobilized water resources and it impacts negatively on water resources through the intensification and extension of irrigated land (Al Atiri, 2009). Considerable efforts have been made to achieve adequate strategies for sustainable management of irrigation water, such as demand management, water conservation and pricing policy. The evaluation of these strategies has always been criticized by local actors during the drought years. Indeed, the sustainability of irrigated agricultural activity requires not only a water saving policy (Jeder et al., 2019), but also a strategy for a better allocation of these available resources during unfavorable climatic years.

In Tunisia, the responsibility of irrigation water distribution is assigned to the Agricultural Development Group (GDA). These (GDA) are local institutions of collective agricultural development which are also responsible for the man-

\footnotetext{
* Regional Center of Research in Horticulture and Organic Agriculture (CRRHAB), Sousse / Laboratory of economy and rural communities, Arid Regions Insitut (IRA), Medenine, Sousse, Tunisia.

** Higher School of Agriculture of Mograne (ESA, Mograne), Tunisia.

Corresponding author: djederhoucine@yahoo.fr
} 
agement of irrigation water. Unlike other countries in the world which have created a market for water, the government of Tunisia has adopted a potential monopoly on water to manage a common resource instead of the privatization of this resource. This potential monopolization is considered to be a privileged mechanism in Tunisia for the management of water resources. It is justified by the importance of the social dimension of the irrigation water needs in a country characterized by a modest economy based on household farming (Livingston, 1993; Young, 1986; Colby, 1990), and also social equity, which imposes a water pricing policy is always lower than the real cost of production (Howe et al., 1986; Brookshire et al., 2004). These arguments make the idea of privatizing common resources through the creation of a water market almost difficult in Tunisia. However, transferring water between regions or between available sources of water in a single region is relatively possible for optimal management of irrigation water resources. Good management of water resources requires a good allocation of their availability, especially in the public irrigated schemes in Tunisia. This paper contributes to a better reallocation of available water resources at the farm and regional level. Several works in Tunisia have tackled about the problem of allocation of water resources through a normative approach aimed at saving water through economic regulation instruments such as pricing policy (Sghaier, 1995; Thabet, 2003; Bachta et al., 2004; Frija et al., 2015). Other works on the management of water resources in Tunisia have adopted a bioeconomic approach by coupling the mathematical programming model to a biophysical model such as CropSyst, Epic, Apsim, and CropWat... etc. This bioeconomic modeling aims to integrate the physical and environmental assessment of certain problems like erosion and soil salinity for adaptation to climate change (Louhichi, 2001; Jeder et al., 2011). Another research work was carried out by Azizi (2018) on farmers' behavior towards the demand for irrigation water and the possibility of improving the pumping cost via the increase in the cost of electricity and the improvement collective distribution services. These bioeconomic models of pos- itive mathematical programming, integrating also the notion of risk in agricultural activity, have succeeded in showing the effectiveness of certain possible strategies or scenarios on agricultural production systems. Although the bioeconomic modeling used meets the designated objective, the constraint of water availability has remained static and the resolution of these models, or the simulation of scenarios, have been tested while respecting this constraint. So the idea in this paper is to make this constraint flexible through a proposal for a reallocation of available water resources via the transfer of water between sources available to irrigate public schemes.

This paper will therefore illustrate a case study for a reallocation of irrigation water resources through a regional agricultural model based on aggregation between farm-types, using mathematical programming inspired from the theory of microeconomics (Hazell and Norton, 1986). The rest of the article will be structured in two parts: one part is devoted to the representation of the modeling methodology approach adopted, and then the presentation of the study area and the data collected, the last part is devoted to the analysis and discussion of the results and finally the conclusion.

\section{Methodology, case study and data sources}

\subsection{Mathematical programming as an analysis tools in agriculture}

Mathematical programming (MP) has become an important analytical tool and widely used in agricultural economics. The basic motivation for using programming models in agricultural economic analysis is straightforward, because the fundamental economic problem is making the best use of limited resources (Mills, 1984). The use of optimisation models is therefore a perfect combination with the neoclassical economic theory, which perceives economic agents as optimisers. Following linear programming model in its primal form illustrates the use of mathematical programming in agricultural economics (Equations a \& b). 


$$
\max Z=\sum_{j} c_{j} x_{j}
$$

Subject to:

$$
\begin{gathered}
\sum_{j} c_{i j} x_{j} \leq b_{i} \\
x_{j} \geq 0
\end{gathered}
$$

Where: $c_{j}$ is the forecasted gross margin of farm activity $\mathrm{j}, x_{j}$ is the level of farm activity $\mathrm{j}$, $a_{i j}$ is the quantity of resource i required to produce one unit of activity $\mathrm{j}, b i$ is the amount of available resource $\mathrm{i}$ and $i$ is the index of resource and $\mathrm{j}$ is the index of activities.

Mathematical programming (MP) has evolved considerably, losing the features of a pure farm management instrument. Presently, it is an important instrument of policy analysis at farming, regional and national levels, with the objective of analysing the impact of agricultural policies on the socio-economic and environmental of farming production systems (Salvatici et al., 2000). An extension to multi-objective and goal programming techniques even allows finding the best compromise in the case of conflicting objectives (Romero and Rehman, 1989). For example economic objective is maximizing total agricultural income and an environmental objective minimizes agricultural pollution from nitrates leaching and percolation (Fragoso et al., 2010). Mathematical programming can be normative mathematical programming (NMP) (as in our case) or positive mathematical programming (PMP). The difference between them is that in programming (NMP), the parameters of the objective function and the constraints are not calibrated. This means that to build an NMP model, basic system knowledge is sufficient. On the other hand, in positive mathematical programming (PMP), certain parameters are adjusted to be able to reproduce exactly a given baseline; the method is called positive (Howitt, 1995). Another alternative to calibrating the model with econometric mathematical programming (EMP) is based on the estimation of optimality conditions. The parameters of the model were estimated using the entropy approach and previous information (Fragoso and Marques, 2015).

\subsection{Arguments for using normative mathematical programming model}

Normative mathematical programming model (NMP) has been used in agricultural economics for a long time. This normative model determines the levels of different variables in order to optimize the objective set by the decision maker (Hazell and Norton, 1986). Usually this concerns, for example, the maximization of the farmer's income or gross margin. Targets and decision variables can include economic, ecological or social aspects of the system, which again highlights the possibility of a multidisciplinary approach in programming models.

In our case, the justification for the use of normative mathematical programming is mainly linked to our research objective. Therefore, the objective is to have better management of the water resources available in the study region to counter the challenges of climate change. The originality of this paper is not to make an impact study of such a scenario or a policy, which requires a calibration of the model by positive mathematical programming, but to propose a better reallocation of resources in inter-temporal and inter-perimeter. The genesis of the idea of reallocation of water resources is not only theoretical but pragmatic and feasible since the transfer of water between these two irrigation schemes is possible because these schemes share the same irrigation networks. So, the objective of using normative mathematical programming is to know how this reallocation could be achieved between these two perimeters during the agricultural season. At the same time, the objective is to assess the economic, agronomic and social impacts of this new reallocation at farms and regional levels in terms of agricultural income, water consumption and also the need for salaried labor by period (summer, winter).

\subsection{Overview of the model}

To respond to the problems and challenges of optimal water management to face to climate change, we propose a regional modeling framework. The regional model developed integrates agronomic, hydraulic and socio-economic data. 
It can simulate the behavior of farmers taking into account competition for availability resources and the possibility of transferring irrigation water between the two main resources of the region during the agricultural season. Using the aggregation technique, the adopted regional model simulates the interactions between agricultural farms such as the transfer of common resources (Louhichi et al., 2014). It also makes possible to aggregate the results of farms at the regional level. With this technique, the objective function of the regional agricultural model becomes the regional gross margin maximization based on the weighted gross margin sum of each representative farm (equation1) under a set of constraints (Abbes, 2005).

$$
\operatorname{Max} U=\sum_{h} w_{h} Z_{h}
$$

Where $\mathrm{h}$ denotes the farm type and $w_{h}$ is the weight of each representative farm-type $h$ within the region. $U$ is the regional gross margin and $Z_{h}$ is the gross marginal at the farm type level. This gross marginal farm $Z_{h}$ is defined as total gross marginal including sales from agricultural products minus total variable costs from crop production. Total variable costs include accounted linear costs for fertilizers, irrigation water, crop protection, seeds and plant material and cost of hired labour. Using mathematical notation, the linear gross marginal farm function $Z_{h}$ can be presented as follow:

$$
\begin{gathered}
\operatorname{Max} Z_{h}=\sum_{i=c, t}\left(R D T_{c} * P_{C}-C V_{c, t}\right) X_{c, t} \\
-\sum_{c, t, p}\left(\operatorname{beau}_{c, t, p} * P_{w} * X_{c, t}\right)-\sum_{p}\left(T L_{p} * P_{l}\right)
\end{gathered}
$$

$P_{C}$ is the producer price of crop $\mathrm{c}, \mathrm{t}$ is production technique (irrigated and rainfed), $p$ is the period or season (The winter period "P1" is from September to February and the summer period "P2" is from March to August). $R D T_{c}$ is the yield expressed by crop c. $C V_{c, t}$ is the average cost of crop production per techniques and period excluding water and labor costs. $P_{w}$ is the irrigation water price and $P_{l}$ is the wages of labor. $b_{e a u_{c, t, p}}$ is the water requirement of each crop cultivated. $T L_{p}$ is the amount of tempory labour used per period $P$. Finally, $X_{c, t}$ is the variable of the production activity, defined as be- ing the crops area in different farm-type. This modeling approach consists of maximizing an objective function of gross margin with a set of constraints. The constraints at the farm level are as follows:

$$
\begin{aligned}
& \sum_{c, t} X_{c, t} \leq L A N D \\
& \sum_{c, t i} X_{c, t i} \leq L A N D \_I R R G \\
& \sum_{o l i v, t i} X_{o l i v, t i}=X_{o l i v, t i}^{0} \\
& \sum_{c e r, t r} X_{c e r, t r} \leq \frac{1}{4} * \sum_{v g, t i} X_{v g, t i} \\
& \sum_{c, t, p} b l_{c, t, p} * X_{c, t} \leq D L_{p}+T L_{P} \\
& \sum_{c, t i, h, p} \text { bwater }_{c, t i, p} * X_{c, h, t i} \leq \text { avwater }_{h, p} \\
& \sum_{c, t i} b_{\text {water }}{ }_{c, t i, h, p} * X_{c, t i} \leq a v_{-} \text {water }_{h, p}- \\
& \text { am_water } r_{\text {reallocated, } h, p}
\end{aligned}
$$

Constraint (3) is a land constraint, indicating that the total cultivated areas in each farm-type should not exceed the currently observed agricultural areas. Constraint (4) indicates that the sum of crops irrigated areas should not exceed the total irrigable areas available in each farmtype. The constraint (5) is the area constraint of the arboriculture, in particular the olive tree, which must be constant and equal to the area observed. Constraint (6) is the constraint of crop rotation, indicating that the area of cereals crops (barley and wheat) must not exceed 1/4 of the areas of vegetables crops (annual crops). Constraint (7) is the labour constraint, indicating that the sum of labour required for each crop, expressed in hour per period, should be less than the amount of labour available in the farm, additional to plus the amount of temporary labour (salaried) if needed. The temporary labour is an endogenous variable calculated by the model itself. The farmer has an economic interest in employing salaried labor when the opportunity cost of one hour is higher than the real cost (15 Dinars / 8 hours). Constraint (8) indicates that the sum of water requirement of all crops cultivated should not exceed the water availability at farm-type level minus the amount of water allocated to other farms when possible. 
The constraints at the regional level are as follows:

$$
\begin{aligned}
& \sum_{h, p} a_{-} \text {water }_{h, p} * w_{h}= \\
& \sum_{h, p} \text { am_waterr } r_{\text {reallocated, } h, p} * w_{h} \\
& \sum_{h, p} a v_{-} \text {water }_{h, p} * w_{h}= \\
& \text { av_water }{ }_{\text {public boreholes }} \\
& \sum_{h, p} \text { av_water }{ }_{h, p} * w_{h}= \\
& a v \_ \text {water }_{\text {dam Nenhana }} \\
& \sum_{h, p} T L=T L_{h, p} * w_{h}
\end{aligned}
$$

The regional constraints (10), (11) and (12) are used in the aggregate model to calculate the total quantity of water reallocated at the regional level which must not have access to water availability in the agricultural area "Balôum" and "Chiyab" (Figure 1). The constraint (13) is used to calculate the total amount of time work employed in the region.

\subsection{Case study}

The agricultural perimeter of Kalâa Kebira is located in the governorate of Sousse in the CenterEast of Tunisia (Figure 2). It was created in 2003, and formed by two public perimeters according to the agricultural zone: public perimeter, called "Balôum", irrigated by public boreholes, and the other public perimeter, called "Chiyab" irrigated by dam of "Nebhana". The agricultural region of Kalâa Kebira is occupied by the potato crop on large surfaces in rotation with other vegetable crops such as pepper, tomato and cereals crops. All these crops are intercropped with olive trees. This perimeter occupies an area of 540 ha and is managed by the Agricultural Development Group (GDA). The price is approximately $0.240 \mathrm{TD} 1 /$ $\mathrm{m}^{3}$, this volumetric water pricing is applied in the perimeter of Kalâa Kebira (Ben Hamza, 2017).

\subsection{Source and data collection}

The data used to feed the regional agricultural model was of different types and thus collected from various sources. Specific crops inputs and outputs levels for different agricultural zones were collected through farmer's surveys which
Figure 1 - Methodological modeling framework (inspired by Hazell and Norton, 1986).

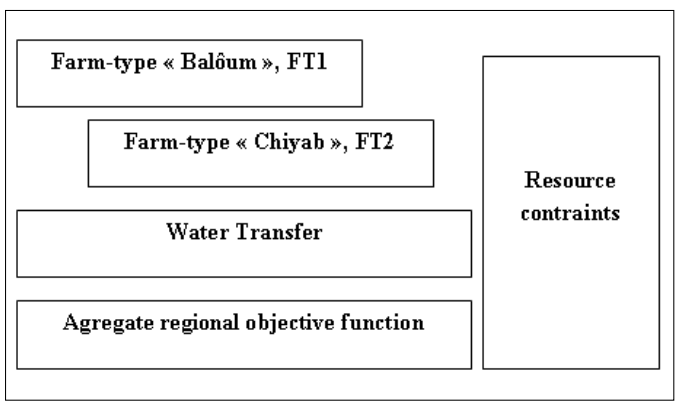

Figure 2 - Case study: Kalâa Kebira region, Sousse governorate, Center-East of Tunisia.

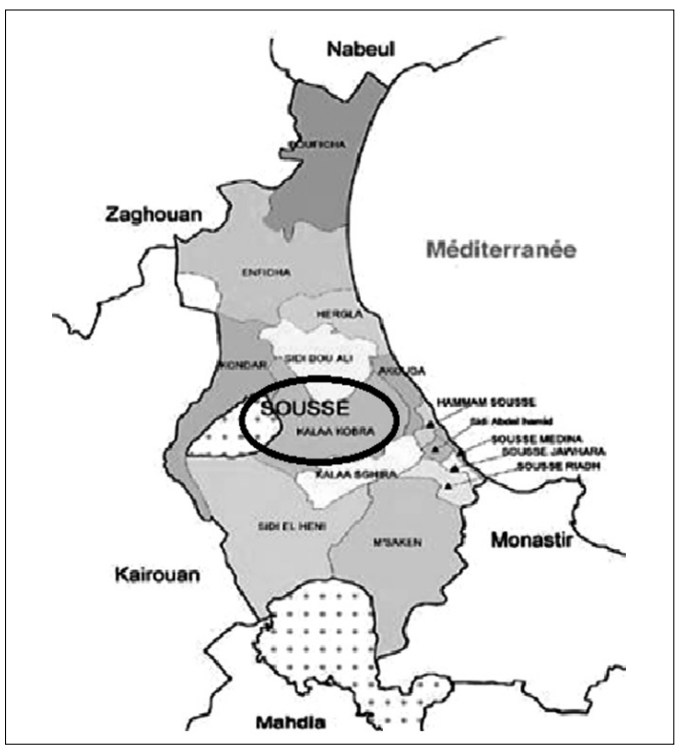

were conducted during season 2018-2019. These data were collected from 45 farmers in the region. A simple classification according to the agricultural zone and the sources of irrigation water makes it possible to obtain two farms-types. The first typical farm (FT1) is representative of the agricultural zone "Balôum", whose main source of irrigation is the public water boreholes and the second farm-type (FT2) represented the "Chiyab" agricultural zone, of which the main source of irrigation is the "Nabhana" dam.

These two farms-types are almost similar; they have the same agricultural crops practiced and even structural variables except for the irrigable land and crops areas. In the case of the 
Table 1 - Representative and characteristic of farm type in "Kalâa Kebira".

\begin{tabular}{|c|c|c|}
\hline Farm-Type characteristics & $\begin{array}{c}\text { Farm-type "Baloum" } \\
\text { FT1 }\end{array}$ & $\begin{array}{c}\text { Farm-type "Chiyab" } \\
\text { FT2 }\end{array}$ \\
\hline \multicolumn{3}{|l|}{ Agricultural crops (ha) } \\
\hline Seasonal potato (PTS) & 2.81 & 1.79 \\
\hline Potato back season (PTAS) & 3.10 & 2.21 \\
\hline Primary potato $(\mathrm{PTP})$ & 1.40 & 0.53 \\
\hline Tomato (TOM) & 0.38 & 0.11 \\
\hline Pepper (PEPER) & 0.50 & 0.84 \\
\hline Barley (BL) & 0.77 & 0.55 \\
\hline Wheat (WH) & 1.50 & 0.26 \\
\hline Fallow (FALL) & 0.04 & 3.12 \\
\hline Olives (OLIV) & 1.21 & 1.06 \\
\hline Total agricultural area (ha) & 11.71 & 10.47 \\
\hline Irrigable area (ha) & $9.12(77 \%)$ & $8.25(78 \%)$ \\
\hline Family labor in winter (P1) ( (hours) & 256.15 & 241.58 \\
\hline Family labor in summer (P2) (hours) & 277,79 & 297.24 \\
\hline \multicolumn{3}{|l|}{ Total water availability at farm level } \\
\hline Available water in winter $(\mathrm{P} 1)\left(\mathrm{m}^{3}\right)$ & 12791.99 & 14322.67 \\
\hline Availability of water in summer $(\mathrm{P} 2)\left(\mathrm{m}^{3}\right)$ & 13502.65 & 6740.08 \\
\hline \multicolumn{3}{|l|}{ Availability of total water at the scale of agricultural zone } \\
\hline Source of water dam "Nabhana" $\left(\mathrm{m}^{3}\right)$ & 842510 & \\
\hline Source of water from public boreholes $\left(\mathrm{m}^{3}\right)$ & & 710666 \\
\hline \multicolumn{3}{|l|}{ Regional representation (weight) (\%) } \\
\hline Total number of farmers in the public perimeter irrigated & \multicolumn{2}{|c|}{101} \\
\hline The weight of the representativeness of Farm-type & $25 \%$ & $20 \%$ \\
\hline
\end{tabular}

Source: survey data, 2019.

farm-type (FT1), the irrigable land represents $77 \%$ of the total agricultural area whereas for the case of the farm-type (FT2) it represents $78 \%$ of the total agricultural area (Table 1). This difference explains that irrigation water could a limiting factor for agriculture in the absence of good management of irrigation water.

\section{Results and discussion}

\subsection{Farm income}

At the farm level, the results of the regional model with transfer show a significant improvement in FT1 agricultural farm income of
$19.02 \%$ to obtain an annual income of about DT 98827.71 against a decline in farm income FT2 of $23.13 \%$ with an annual income that does not exceed 53993.2 DT (Table 2). This contradiction expressed by the regional model with water transfer shows a high competitiveness at the farm level FT1 for use of available resources especially irrigation water. Today, the competitiveness of water use is a good criterion for valuing water by farmers not only in economic terms but also in terms of the sustainability of this resource.

At regional level, the results of the regional model with transfer of water between the two agricultural zones shows a regional income improvement of $2.12 \%$ approximately 3573943.48 TD per 
Table 2 - Impact water transfer on farm income.

\begin{tabular}{|l|c|c|c|}
\hline \multirow{2}{*}{ At Farm level } & \multicolumn{3}{|c|}{ Farm income (DT) } \\
\cline { 2 - 4 } & $\begin{array}{c}\text { Regional model without } \\
\text { transfer of water }\end{array}$ & $\begin{array}{c}\text { Regional model with } \\
\text { transfer of water }\end{array}$ & $\begin{array}{c}\text { Variation of farm } \\
\text { income\% \% }\end{array}$ \\
\hline Farm-type "Baloum" FT1 & 83037.17 & 98827.71 & +19.02 \\
Farm-type “Chiyab" FT2 & 696402.82 & 53393.26 & -23.13 \\
At regional level & 3499837.7 & 3573943.48 & +2.12 \\
\hline
\end{tabular}

year against the regional model without transfer of water who does not exceed 3499837.7 TD. This transfer of water between these two perimeters is possible in reality since they have the same irrigation network as well as the positive contribution of the community to improve the regional agricultural economy and the competitiveness on the valorization of water resources in this region (Table 2).

\subsection{Temporal labor use}

The results in Table 3 have shown that the endogenous variable in the use of temporal labor use by period is calculated by the model according to the characteristics of the farm and their water consumption. Indeed in the case of the regional model without transfer of water, we note that the agricultural farm (FT1) uses 230 hours of temporal labor during the winter period (P1) whereas in the case of the regional model with transfer of water, this same farm uses only 17.03 hours of time work during the winter period (P1). Whereas, the agricultural farm (FT2) does not use temporal labor and only uses family labor. The weighting (the type of farm in the region) shows the same trend in the use of temporal labor on a regional level with 5826.42 hours during the winter peri- od (P1) while 433.32 hours during the summer period (p2) (Table 3). It can be said that the substitutability between the quantities of the factors of production (labor and water) depends on the opportunity cost of these factors. The use of temporal labor distinguishes between household farm which is based on family labor and commercial farm which is based on temporal labor. This regional model shows that the water factor plays a more important role in the dynamics and variability of temporal labor use on commercial farms which always seeks to maximize their economic gains. Indeed, the commercial farms always require temporal labor to increase both their production and their income, while the agricultural household programs its activities according to the available family labor. Today in Tunisia and especially in the Mediterranean countries, the agricultural policy must encourage farm households towards modernization to increase national production and employ more agricultural labor in the rural environment.

\subsection{Land use}

The objective of using the normative modeling approach in agricultural economics is to propose an optimal production plan which shows that

Table 3 - Impact of water transfer on the temporal labor used.

\begin{tabular}{|l|c|c|}
\hline \multirow{2}{*}{ At Farm level } & \multicolumn{2}{|c|}{ Temporal labor used (Hours) } \\
\cline { 2 - 3 } & $\begin{array}{c}\text { Regional model without } \\
\text { transfer of water }\end{array}$ & $\begin{array}{c}\text { Regional model with } \\
\text { transfer of water }\end{array}$ \\
\hline Farm-type "Baloum" FT1 at period P1 & & 17.07 \\
\hline Farm-type "Baloum" FT1 at period P2 & 230.75 & \\
\hline Regional level & 5826.42 & 431.12 \\
\hline
\end{tabular}


Figure 3 - Land use impact of water transfer at farm level.

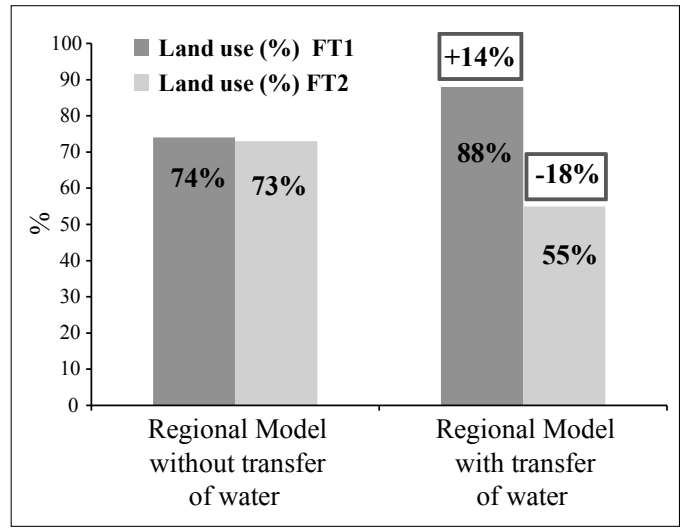

preserving the use of available resources makes it possible to guarantee maximum agricultural income. So, the result of modeling at the regional level shows that the preservation of the land resource is possible with an optimal allocation. Thus, the regional modeling with water transfer shows that the land occupancy rate has increased by $14 \%$ for farm FT1 (Balôum) against a decrease of $18 \%$ for farm FT2 (Chiyab) (Figure 3). This increase in the agricultural land use rate is accompanied by an increase in the gross margin at the regional scale and at the scale of the most competitive farms, such as farms FT1 (Balôum). These results show that regional agricultural de- velopment requires economic optimality in the use of available natural resources and competitiveness between agricultural farms. In Tunisia, land degradation is also due to the lack of instruments of land use policies such as the obligation to fallow, agricultural rotation and the categories of land owners. The criteria for using scarce resources such as land or water must be based on two fundamental concepts; resource efficiency and competitiveness. The conflict of interest between individualism and collectivism must not be resolved by the unreasoned intensification of scarce natural resources.

\subsection{Crops areas}

The increase in land use is explained firstly by the increase in the availability of water by transfer secondly by the area of the cultivated crops. The results of this model also show the diversification of crops and the specification of the agricultural production system. At the farm level, like the FT1 farm, the integration of the seasonal potato crop (PTS) over an area of 2.76 ha and the increase in the area of barley (BL) at 1.81 ha and also the area of late season potato (PTAS) at 4.07 against the decrease in the area of pepper to 0.41 ha (Figure 4). But, on the farm FT2 (Chiyab), an increase in the area of pepper (PEPR) to 1.32 ha in favor of the late-season po-

Figure 4 - Impact of water transfer on crop areas at farm level.

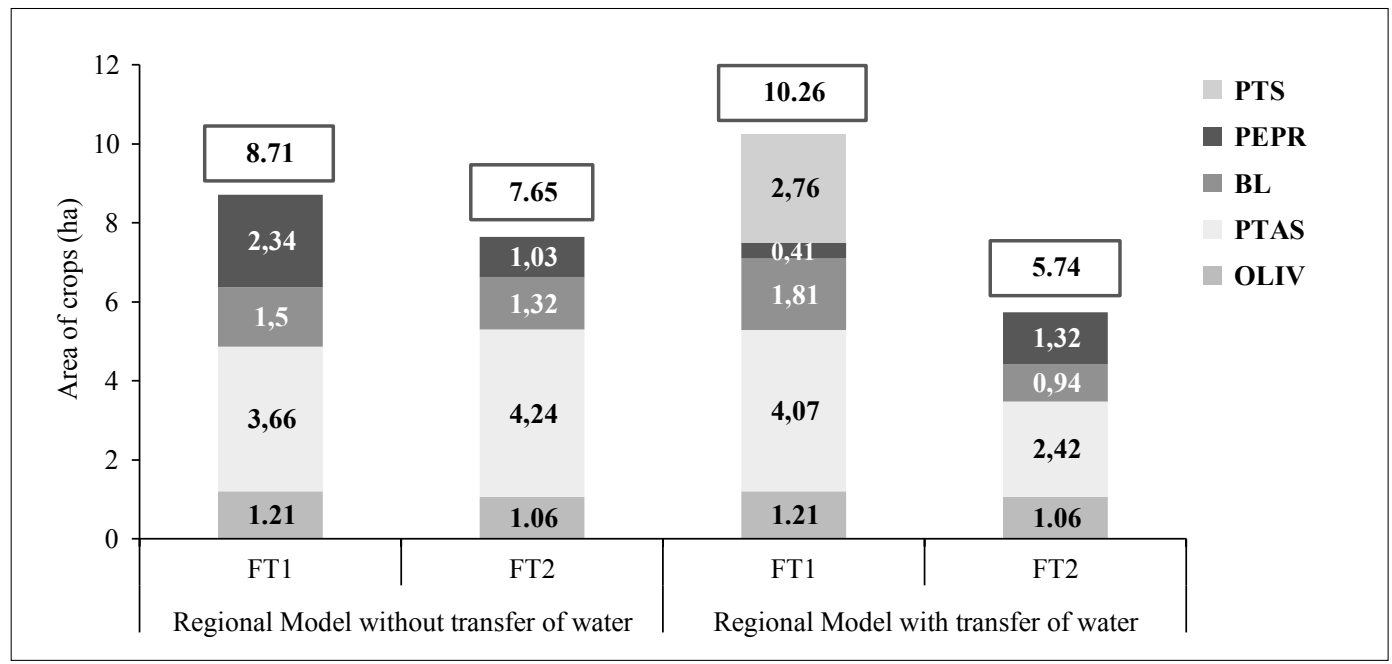


tato crop (PTAS) and barley (BL). For the area of the olive tree as an arboriculture, the area is considered a static variable that does not enter into the optimal choice of land use (Figure 4). These results show that water transfer increases not only the competitiveness in the use of water resources, but it also contributes to the diversification of crops and agricultural production systems practiced. In the case of "Kalâa Kebira", the farms (Baloum) have a tendency to cultivate the most profitable crops for them such as seasonal and late season potatoes (PTS and PTAS), while the farms (Chiyab) have a tendency to cultivate the cultivation of pepper (PEPR) to maintain their agricultural income. At the regional level, diversification is important for the optimal use of available resources, especially water and land. It is also advantageous for the balance between supply and demand on the local market for certain strategic crops for the Tunisian consumer, such as potatoes.

\subsection{Water reallocation}

The water consumption constraint is saturated for the two periods according to the results obtained by the regional model without water trans- fer, and the farmers use all the water availability. On the other hand, the regional model with the possibility of transfer proposes a new reallocation with a high regional income according to a criterion of competitive use of water resources. Thus, an increase in water consumption at the farm level FT1 (Balôum) is observed for the period (P1) following a transfer of a quantity of water $(\mathrm{e} 2=$ $5477.01 \mathrm{~m}^{3}$ ) from the farm FT2 (Chiyab) to meet the water requirement for the cultivated crops. The period (P1) is the winter period, when the availability of water in the "Nabhana" dam is important, especially during the rainy years. Consequently, the water consumption for the period (P1) at farm level FT1 (Baloum) becomes the sum of the water availability (a) and the transferred quantity (e2) from the farm FT2 (Chiyab), this consumption is equal to $18268.99 \mathrm{~m}^{3}(12791.99$ (a) +5477.01 $(\mathrm{e} 2)=18268.99 \mathrm{~m}^{3}$ ) (Table 4). For the farm FT2 (Chiyab), consumption increases for the period (P2) which corresponds to the summer period when the availability of water at the "Nabhana" dam is low. Thus the consumption during the period (P2) for the farm FT2 (Chiyab) becomes the sum of the water availability (d) and the transferred quantity (e1) which is equal to $8197.99 \mathrm{~m}^{3}$ $\left((\mathrm{d})+(\mathrm{e} 1)=8197.99 \mathrm{~m}^{3}\right)$. Conversely, following

Table 4 - Impact of water reallocation at farm and regional levels.

\begin{tabular}{|c|c|c|}
\hline \multicolumn{3}{|c|}{ Regional model without transfer water } \\
\hline Water availability $=$ Water use & Farm FT1 (Balôum) & Farm FT 2 (Chiyab) \\
\hline Period P1 $\left(\mathrm{m}^{3}\right)$ & 12791.99 (a) & $14322.67(\mathrm{c})$ \\
\hline Period P2 $\left(\mathrm{m}^{3}\right)$ & $13502.65(\mathrm{~b})$ & $6740.08(d)$ \\
\hline \multicolumn{3}{|c|}{ Regional model with transfer water } \\
\hline Reallocation of water at farm level & Farm FT1 (Balôum) & Farm FT 2 (Chiyab) \\
\hline Transfer of water in P1 $\left(\mathrm{m}^{3}\right)$ & & $5477.01(\mathrm{e} 2)$ \\
\hline Transfer of water in P2 $\left(\mathrm{m}^{3}\right)$ & $1457.91(\mathrm{e} 1)$ & \\
\hline Total reallocation of water at farm level & Farm FT1 (Balôum) & Farm FT 2 (Chiyab) \\
\hline Water use in period $\mathrm{P} 1\left(\mathrm{~m}^{3}\right)$ & (a) $+(\mathrm{e} 2)=18268.99$ & $(c)-(e 2)=8845.66$ \\
\hline Water use in period $\mathrm{P} 2\left(\mathrm{~m}^{3}\right)$ & (b) $-(\mathrm{e} 1)=12044.74$ & (d) $+($ e1) $=8197.99$ \\
\hline \multicolumn{3}{|l|}{ Reallocation of water at regional level } \\
\hline Total of transfer of water in $\mathrm{P} 1\left(\mathrm{~m}^{3}\right) ;(\%)$ & \multicolumn{2}{|c|}{$110635.63 ;(7.20 \%)$} \\
\hline Total of transfer of water in $\mathrm{P} 2\left(\mathrm{~m}^{3}\right) ;(\%)$ & \multicolumn{2}{|c|}{$36812.22 ;(2.39 \%)$} \\
\hline Total regional reallocation of water $\left(\mathrm{m}^{3}\right) ;(\%)$ & \multicolumn{2}{|c|}{$147447.82 ;(9.60 \%)$} \\
\hline
\end{tabular}

Source: models results. 
this water transfer, a decrease in water availability will be recorded for the period (P1) on the scale of the farm FT2 (Chiyab), the constraint is unsaturated and the consumption is $8845.66 \mathrm{~m}^{3}$ $\left(14322.67\right.$ (c) $\left.-5477.01(\mathrm{e} 2)=8845.66 \mathrm{~m}^{3}\right)(\mathrm{Ta}-$ ble 4). Similarly, a decrease in water availability will be recorded for the period (P2) on the scale of farm FT1 "Balôum". At the regional level, this new reallocation shows a seasonal transfer of water between these two sources of irrigation in the order of $110635.63 \mathrm{~m}^{3}(7.20 \%)$ for the period (P1) and $36812.22 \mathrm{~m}^{3}$ (2.39\%) for the period (P2), with a total of exchange about 147447.82 $\mathrm{m}^{3}$ representing $9.60 \%$ of total water availability (Table 4).

This new reallocation of water resources makes it possible to increase regional agricultural income through competition and high competitiveness on the use of this resource. This competitiveness privileges the commercial farms like the farm FT1 (Bâloum) for the benefit of the household farms like farm FT2 (Chiyab). This reallocation of water resources through a regional model of water transfer confirms the concept of Pareto for optimality and competitiveness which privileges the increase in the utility of an agent without decreasing that of the other agent on the use of this resource (Samuelson, 1947).

The results obtained from the regional model applied with a seasonal water transfer show that the reallocation of water is possible for the agricultural development of the region and the preservation of the resource. Better allocation requires efficient inter-user and inter-temporal management of the available resource. Today, water management requires a reallocation approach based on the competitiveness and efficiency of use between the different actors. This study also confirms the rise of the opinion of several political decision-makers of the need to transfer water between different regions and different water storage dams as an alternative strategy to overcome the hydraulic imbalances caused by rainfall irregularity.

\section{Conclusion}

This study made it possible to propose a new reallocation of available water resources through a periodic (seasonal) transfer of water to irrigate the two irrigated areas in the Kalâa Kebira region, in center-eastern Tunisia. The transfer of water and the optimality criterion imposed by the regional model have shown a high competitiveness in the use of water resources for commercial farms (FT1, Balôum) versus household farms (FT2, Chiyab). This competitiveness can play an important role in balancing supply and demand in the local market for agricultural products.

The regional model of reallocation of irrigation water resources in this research could be seen as a good example of optimal and economical allocation that could be applied in other regions. These recommendations could also be used in water policy in Tunisia to think about water transfer as an alternative strategy, despite the expensive cost of this transfer. But these repercussions and these economic opportunities could be promising to climate change accentuated in the Mediterranean regions, in particular Tunisia.

From a methodological point of view, the approach adopted for regional modeling through normative linear programming has succeeded in meeting the objective of this research for a better reallocation of available water resources, but it is also marked by the presence of certain limits. Among these limits, the absence of integration of crop rotation which can play an important role in saving seasonal water availability (per period) and the importance of taking into account environmental externalities in an intensive agricultural production system. The improvement of this methodological approach in a future work is possible through a regional bioeconomic model of ex-ante evaluation for a set of economic, environmental and climatic political instruments to develop strategies for adapting Tunisian agriculture to the challenge of water scarcity in the future.

\section{References}

Abbes K., 2005. Analyse de la relation agriculture-environnement : une approche bioéconomique. Cas de la salinisation des sols et de la pollution par les nitrates au Nord tunisien. Thèse de doctorat en sciences économiques, Université de Montpellier I. 
Al Atiri R., 2009. Politique du pays en matière de gestion de l'eau. Journée nationale de l'économie d'eau. INAT - Institut National Agronomique de Tunisie, 22 Mars, Tunis.

Azizi A., 2018. Evaluation prospective de la demande en eau agricole et des options de gestion durable de la ressource en eau à l'échelle du territoire irrigué en Tunisie centrale. Thèse de doctorat en Sciences Économiques - INAT / AgroParisTech.

Bachta M.S., Ben Mimoun A., Zaiebet L., Albouchi L., 2004. Simulation of a water market in Tunisia: case study of GIC Melalsa-Kairoun. Actes du Séminaire, Modernisation de l'agriculture irriguée, Rabat, Maroc, 19-23 Avril 2004.

Ben Hamza E., 2017. Analyses de la viabilité socioéconomique et environnementales des nouveaux systèmes de production. Mémoire (Master of Science), CIHEAM-IAMM, Montpellier.

Brookshire D.S., Colby B., Ewers M., Ganderton P.T., 2004. Market prices for water in the semiarid West of the United States. Water Resources Research, 40(9): W09S0401-W09S0408. DOI:10.1029/ 2003WR002846.

Buysse J., Van Huylenbroeck G., Lauwers L., 2007. Normative, positive and econometric mathematical programming as tools for incorporation of multi-functionality in agricultural policy modelling. Agriculture, Ecosystems and Environment, 120: 70-81.

Colby B.G., 1990. Enhancing in stream flow benefits in an era of water marketing. Water Resources Research, 26(6): 1113-1120.

Fragoso R., Marques C., 2015. Alternative irrigation water pricing policies: An Econometric Mathematical Programming Model. New Medit, 14(4): 42-49.

Frija A., Dhehibi B., Chebil A., Villholth K.G., 2015. Performance evaluation of groundwater management instruments: The case of irrigation sector in Tunisia. Groundwater for Sustainable Development, 1: 23-32.

Hazell P.B.R., Norton R.D., 1986. Mathematical programming for economic analysis in agriculture. New York: Macmillan Publisher Company.

Howe C.W., Schurmeier D.R., Shaw W.D. Jr., 1986. Innovative approaches to water allocation: the potential for water markets. Water Resources Research, 22(4): 439-445.

Howitt R.E., 1995. Positive Mathematical Programming. American Journal of Agricultural Economics, 77(2): 329-342.

Ikudayisi A., Adeyemo J., Odiyo J., Enitan A., 2018. Optimum irrigation water allocation and crop distri- bution using combined Pareto multi-objective differential evolution. Cogent Engineering, 5(1): 1-16. https://doi.org/10.1080/23311916.2018.1535749.

Jeder H., Ben Hamza E., Belhouchette H., 2019. An optimal price for sustainable irrigated agriculture in central-eastern Tunisia. New Medit, 18(2): 3-14.

Jeder H., Sghaier M., Louhichi K. 2011. Tarification de l'eau d'irrigation et durabilité des systèmes de production : cas du bassin versant d'Oum Zessar, Sud-est de la Tunisie. New Medit, 10(1): 50-57.

Livingston M.L., 1993. Designing water institutions. Market failures and institutional response. Policy, Research Working Paper No. 1227. Washington, D.C.: The World Bank.

Louhichi K., 2001. Essai de modélisation bio-économique de la relation agriculture-environnement : le cas de l'érosion en Tunisie. Thèse de Doctorat en Sciences Economiques. Université de Montpellier I.

Louhichi K., Gomez y Paloma S., 2014. A farm household model for agri-food policy analysis in developing countries: Application to smallholder farmers in Sierra Leone. Food Policy, 45: 1-13.

Marques Falcão C.A., Fragoso de Sousa R.M, Bushenkov V., 2010. Multi-objective water allocation in the Alqueva Region. New Medit, 9(3): 28-35.

Mills G., 1984. Optimisation in economic analysis. London, UK: George Allen \& Uwin Ltd.

Romero C., Rehman T., 1989. Multiple criteria analysis for agricultural decisions. Developments in agricultural economics. Amsterdam: Elsevier B.V.

Salvatici L., Anania G., Arfini F., Conforti P., De Muro P., Londero P., Sckokai P., 2000. Recent developments in modelling the CAP: hype or hope? Paper presented at the 65th EAAE Seminar 'Agricultural Sector Modelling and Policy Information Systems', March 29-31, Bonn, Germany.

Samuelson P.A., 1947. Foundations of Economic Analysis. Cambridge, MA: Harvard University Press.

Sghaier M., 1995. Tarification et allocation optimale de l'eau d'irrigation dans les systèmes de production de la région oasienne de Nefzaoua (sud de la Tunisie). Ph.D. Thesis, Ghent University, Belgium. Thabet C., 2003. Réforme de la politique des prix de l'eau d'irrigation en Tunisie : approche en équilibre général. Ph.D. Thesis, ENSA de Rennes, France.

World Bank, 2016. High and Dry: Climate Change, Water, and the Economy. Washington, DC: World Bank.

Young R.A., 1986. Why are there so few transactions among water users? American Journal of Agricultural Economics, 68(5): 1143-1151. 